\title{
Correlation of Mean Platelet Volume in Type 2 Diabetes Mellitus
}

\author{
Kalpit Agarwal ${ }^{1}$, Suresh Kumar Sutrakar22, Uday Raj Singh ${ }^{3}$, Yogita Singh Tomar ${ }^{4}$ \\ ${ }^{1}$ Department of Pathology, SSMC, Rewa, Madhya Pradesh, India. ${ }^{2}$ Department of Pathology, \\ SSMC, Rewa, Madhya Pradesh, India. ${ }^{3}$ Department of Pathology, SSMC, Rewa, Madhya Pradesh, \\ India. ${ }^{4}$ Department of Pathology, SSMC, Rewa, Madhya Pradesh, India.
}

\section{ABSTRACT}

\section{BACKGROUND}

Diabetes mellitus is a major global health problem. It is classified as type 1 and type 2 diabetes. The disease and its complications also cause a heavy financial burden on diabetic patients, their families and the society. Mean platelet volume is a measurement of the average size of platelets and varies between 7.5 and $10.5 \mathrm{fl}$. We wanted to study the correlation of MPV and HbA1c.

\section{METHODS}

The present study was conducted in the Department of Pathology, SSMC and SGMH, Rewa (MP) over a period of 18 months on 210 cases. Glucose was measured by GODPOD method, MPV by cell counter and HbA1c by high performance liquid chromatography (HPLC) method. Unpaired t test is used to find out $p$ value by using GraphPad software.

\section{RESULTS}

A total 210 cases were included. 60 cases were non-diabetic (Control Group) and 150 cases were of DMT2. The DMT2 group was further divided into DMT2 (controlled) and DMT2 (uncontrolled) on the basis of levels of HbA1c. MPV in DMT2 vs. nondiabetic was $10.80 \pm 1.32 \mathrm{fl}$ vs. $10.01 \pm 1.12 \mathrm{fl}$ respectively. MPV in DMT2 (uncontrolled) vs. DMT2 (controlled) was $11.07 \pm 1.53 \mathrm{fl}$ vs. $10.39 \pm 0.75 \mathrm{fl}$ respectively.

\section{CONCLUSIONS}

MPV in DMT2 patients was significantly higher than non-diabetic group. MPV in uncontrolled diabetic group (HbA1c $>7 \%$ ) was significantly higher than controlled diabetic group ( HbA1c $<7 \%$ ). Hence MPV along with HbA1c can be a useful diagnostic test as well as prognostic marker of vascular complications in DMT2 patients.

\section{KEY WORDS}

Diabetes Mellitus, Mean Platelet Volume, HbA1c
Corresponding Author: Dr. Suresh Kumar Sutrakar, F 3/1, New Doctors Colony, Rewa-486001, Madhya Pradesh, India. E-mail: sutrakar.skumar35@gmail.com

DOI: $10.14260 /$ jemds/2020/66

Financial or Other Competing Interests: None.

How to Cite This Article: Agarwal K, Sutrakar SK, Singh UR, et al. Correlation of mean platelet volume in type 2 diabetes mellitus. J. Evolution Med. Dent. Sci. 2020;9(05):295-298, DOI: $10.14260 / \mathrm{jemds} / 2020 / 66$

Submission 29-11-2019, Peer Review 10-01-2020 Acceptance 16-01-2020, Published 03-02-2020. 


\section{BACKGROUND}

Diabetes mellitus (DM) is a major global health problem. ${ }^{1,2}$ Diabetes mellitus is increasingly affecting the population across the world and is a complex metabolic syndrome characterized by chronic hyperglycaemia resulting in complications affecting almost all organs of the body. ${ }^{3} \mathrm{DM}$ is classified into two types, Type $1 \mathrm{DM}$ which is characterized by severely reduced insulin levels affecting mostly the young individuals and Type 2 DM characterized by insulin resistance which has higher incidence in adults. ${ }^{4}$ Type 2 Diabetes mellitus (DM) accounts for $80 \%$ of all DM. ${ }^{5}$ Diabetes is fast gaining the status of a potential epidemic in India with $8.7 \%$ diabetic population in the age group of 20 to 70 years. It is predicted that by 2030, 79.4 million individuals may be afflicted with diabetes in India. ${ }^{6}$ Type- 2 DM is considered as a lifelong disease which increases morbidity, mortality and decreases the quality of life. The disease and its complications also cause a heavy financial burden on diabetic patients, their families and society. This is especially true in a developing country like India. The risk of developing Diabetes mellitus type 2 (DMT2) increases with age, obesity and lack of physical activity. Women and individuals with hypertension and dyslipidaemia represent the majority of these patients. Diabetic patients have an increased risk of developing micro and macro vascular diseases, and platelets may be involved as a causative agent with respect to altered platelet morphology and function.7,8 Platelets play a major role in maintaining normal homeostasis. Increased activation of platelet has been implicated in the pathogenesis of vascular complication. Platelets are tiny, discshaped, non-nucleated, flattened structures. They are derived from cytoplasm of megakaryocytes and are well influenced by the patient's general health and nutritional status. Around $65 \%$ of platelets are smooth; disc shaped inert cells whereas the remaining $10-35 \%$ are less clearly defined cells (spherical platelets). MPV is a measurement of the average size of platelet in the blood. Generally, the normal platelet count varies between 1, 50,000 and 4, 00,000/ $\mu$ land normal platelet size varies between 2 to 5 microns. Mean Platelet Volume varies between 7.5 and $10.5 \mathrm{fl} .{ }^{9}$ The size of the platelets depends largely on the density of granules present in them. ${ }^{9}$ The electron microscopy reveals the presence of glycogen as well revealed prominent masses in platelets. ${ }^{9}$ In fact, the major source of energy for platelets is usually glucose which is rapidly taken from plasma. ${ }^{9}$ It is already established that the value of glycated haemoglobin (HbA1c), as a marker of longterm gluco-regulation, should be kept below $7 \%$ in order to reduce the risk of micro-vascular and macro vascular complications in DMT2 patients. ${ }^{10}$ Many biomarkers of diabetic thrombocytopathy have been considered for the implementation in clinical practice. Measurement of most parameters of platelet activity is time-consuming, expensive, requires high sample volume and specialty training. On the other hand, mean platelet volume (MPV) is a simple, quick and easy-to-measure parameter of platelet size, and consequently, of its enzymatic activity and prothrombotic potential. It can be determined by routine automated hemograms at a relatively low cost.

\section{METHODS}

The present study was a prospective case control observational study conducted in Department of Pathology, Shyam Shah Medical College and Sanjay Gandhi Memorial Hospital Rewa (MP) over a period of 18 months on patients aged between 30 to 60 years, diagnosed with Type 2 Diabetes Mellitus and subtyped based on American Diabetic Association Criteria (2013). Random venous blood sample was taken under all aseptic precautions. Two ml blood was taken in EDTA vacutainer and processed for MPV and $\mathrm{HbA1} \mathrm{c}$ within one hour. In our study we have taken 210 cases. We use $4 \mathrm{PQ} / \mathrm{L}^{2}$ formula for sample size where $\mathrm{P}$ is prevalence; $\mathrm{Q}$ is $100-\mathrm{P}$ and $\mathrm{L}$ is allowed error. In our study $\mathrm{P}$ is $15, \mathrm{~L}$ is $5 \%$. After calculating with this formula we got sample size of about 204 , so we took 210 cases.

\section{Inclusion Criteria}

1. Age -30 to 60 years.

2. All non-insulin dependent diabetes mellitus patient attending SSMC Rewa associated SGH and SGMH OPD and IPD for the treatment.

\section{Exclusion Criteria}

Patients suffering from anaemia or any bone marrow disorders, ischemic heart disease, dyslipidaemia, chronic systemic inflammatory disorders, patient with renal failure, patient suffering from thyroid related disorders, pregnant women, patient on anti-platelet drugs and cancer chemotherapy were excluded by asking full clinical history of the patient and clinical examination and other respective laboratory investigation. The diagnosis of diabetes was established according to the ADA criteria. (1) Blood glucose (R) more than $200 \mathrm{mg} / \mathrm{dL}$. (2) Blood glucose (fasting) more than $126 \mathrm{mg} / \mathrm{dL}$. (3) Blood glucose (postprandial) more than $200 \mathrm{mg} / \mathrm{dL}$. After baseline evaluation of the Diabetes Mellitus type 2 (DMT2), patients have been subdivided into two groups according to their HbA1c levels based on American Diabetic Association (2013). (a) DMT2 (controlled group) having HbA1c equal to or less than 7 percent. (b) DMT2 (uncontrolled group) having HbA1c more than 7 percent.

MPV was measured using automated blood cell counter (Mindray BC-5150). HbA1c was calculated by HPLC (TINA Quant). Two ml plain blood sample has also been collected for random, fasting and postprandial blood sugar level estimation by, Glucose oxidase enzymatic method (Bio Systems BA 400).

\section{Statistical Analysis}

Data was entered in Microsoft excel and analysis was done using SPSS version 22. Unpaired test is used to find out $p$ value by using Graph pad software.

\section{RESULTS}

In our study we have taken 210 cases out of which 150 cases were Diabetes Mellitus type 2 (DMT2) cases on the basis of their blood sugar levels. DMT2 cases were further subdivided on the basis of their HbA1c levels. Sixty cases having HbA1c 
less than 7 percent were included in DMT2 (controlled group). Ninety DMT2 cases having HbA1c more than 7 percent were included into DMT2 (uncontrolled group). Sixty Non-diabetic cases were also included as Control non-diabetic.

Table No. 1 show Mean platelet volume (MPV) in DMT2 was significantly High, than the Non-diabetic (control group), i.e. $10.80 \pm 1.32 \mathrm{fl}$ vs. $10.01 \pm 1.12 \mathrm{fl}$ respectively. The $\mathrm{p}$ value was less than 0.0001 . Table No. 2 show that Mean platelet volume (MPV) of DMT2 (uncontrolled group) was significantly higher than DMT2 (controlled group), i.e. $11.07 \pm 1.53 \mathrm{fl}$ vs. $10.39 \pm 0.75 \mathrm{fl}$ respectively. The $\mathrm{p}$ value was 0.0017 .

\begin{tabular}{|c|c|c|c|}
\hline & DMT2 (150) & $\begin{array}{c}\text { Non-Diabetic } \\
\text { (Control Group) (60) }\end{array}$ & $\begin{array}{c}\text { p (<0.05 } \\
\text { Significant) }\end{array}$ \\
\hline MPV (in fl) & $10.80 \pm 1.32 \mathrm{fl}$ & $10.01 \pm 1.12 \mathrm{fl}$ & $<0.0001$ \\
\hline \multicolumn{3}{|c|}{ Table 1. Comparison of MPV in DMT2 and Non-Diabetics } \\
(Control Group)
\end{tabular}

\begin{tabular}{|c|c|c|c|}
\hline & $\begin{array}{c}\text { DMT2 } \\
\text { (Controlled) (60) }\end{array}$ & $\begin{array}{c}\text { DMT2 } \\
\text { (Uncontrolled) (90) }\end{array}$ & $\begin{array}{c}\text { p Value } \\
(<0.05 \text { Significant) }\end{array}$ \\
\hline $\begin{array}{c}\text { MPV } \\
\text { (in fl) }\end{array}$ & $10.39 \pm 0.75 \mathrm{fl}$ & $11.07 \pm 1.53 \mathrm{fl}$ & $<0.0017$ \\
\hline \multicolumn{4}{|c|}{ Table 2. Comparison of MPV in DMT2 (Controlled) and } \\
DMT2 (Uncontrolled)
\end{tabular}

\begin{tabular}{|c|c|c|c|c|c|}
\hline \multirow[b]{2}{*}{$\begin{array}{l}\text { Sl. } \\
\text { No. }\end{array}$} & \multirow[b]{2}{*}{ Authors } & \multirow[b]{2}{*}{ Year } & \multicolumn{2}{|c|}{ MPV } & \multirow{2}{*}{$\begin{array}{c}\text { p Value } \\
\text { (<0.05 } \\
\text { Signi- } \\
\text { ficant })\end{array}$} \\
\hline & & & $\begin{array}{c}\text { Non-Diabetic } \\
\text { (Control Group) }\end{array}$ & $\begin{array}{l}\text { DMT2 } \\
\text { Group }\end{array}$ & \\
\hline 1. & Hekimsoy et $\mathrm{al}^{7}$ & 2004 & $9.51 \pm 0.86 \mathrm{fl}$ & $10.62 \pm 1.71 \mathrm{fl}$ & 0.00 \\
\hline 2. & Zuberi et $\mathrm{al}^{8}$ & 2008 & $8.63 \mathrm{fl}$ & $9.34 \mathrm{fl}$ & 0.000 \\
\hline 3. & Demirtunc et al ${ }^{11}$ & 2009 & $8.2 \pm 0.7 \mathrm{fl}$ & $8.7 \pm 0.8 \mathrm{fl}$ & 0.002 \\
\hline 4. & Jindal et al ${ }^{12}$ & 2011 & $11.42 \pm 1.40 \mathrm{fl}$ & $12.08 \pm 1.54 \mathrm{fl}$ & 0.015 \\
\hline 5. & S. Dindar et al ${ }^{13}$ & 2013 & $10.23 \pm 1.02 \mathrm{fl}$ & $10.91 \pm 1.11 \mathrm{fl}$ & 0.001 \\
\hline 6. & AclanOzder et al ${ }^{14}$ & 2014 & $10.04 \pm 1.01 \mathrm{fl}$ & $10.49 \pm 0.96 \mathrm{fl}$ & 0.000 \\
\hline 7. & Alhadas et al ${ }^{15}$ & 2016 & $8.27 \pm 1.244 \mathrm{fl}$ & $8.69 \pm 1.288 \mathrm{fl}$ & 0.018 \\
\hline 8. & Pujari et al ${ }^{16}$ & 2017 & $8.08 \pm 0.45 \mathrm{fl}$ & $9.09 \pm 0.9 \mathrm{fl}$ & $<0.0001$ \\
\hline 9. & Present study & 2019 & $10.01 \pm 1.12 \mathrm{fl}$ & $10.80 \pm 1.32 \mathrm{fl}$ & $<0.0001$ \\
\hline
\end{tabular}
(Control Group) and DMT2 Group in Various Studies

\begin{tabular}{|c|c|c|c|c|c|}
\hline \multirow[b]{2}{*}{$\begin{array}{l}\text { Sl. } \\
\text { No. }\end{array}$} & \multirow[b]{2}{*}{ Authors } & \multirow[b]{2}{*}{ Year } & \multicolumn{2}{|c|}{ MPV } & \multirow{2}{*}{$\begin{array}{c}\text { p Value } \\
(<0.005 \\
\text { Signi- } \\
\text { ficant })\end{array}$} \\
\hline & & & $\begin{array}{c}\text { DMT2 } \\
\text { (Controlled } \\
\text { Group) }\end{array}$ & $\begin{array}{l}\text { DMT2 (Un- } \\
\text { controlled } \\
\text { Group) }\end{array}$ & \\
\hline 1. & Demirt & 2009 & $8.4 \pm 0.8 \mathrm{fl}$ & $9.0 \pm 0.6 \mathrm{fl}$ & 0.003 \\
\hline 2. & Kodiatte et $\mathrm{al}^{3}$ & 2012 & $8.2 \pm 0.74 \mathrm{fl}$ & $8.35 \pm 0.73 \mathrm{fl}$ & 3 \\
\hline 3. & S. Dindar et al ${ }^{13}$ & 2013 & $10.29 \pm 0.87 \mathrm{fl}$ & $11.53 \pm 0.96 \mathrm{fl}$ & $<0.001$ \\
\hline 4. & AclanOzder et al ${ }^{14}$ & 2014 & $10.17 \pm 0.83 \mathrm{fl}$ & $10.80 \pm 0.92 \mathrm{fl}$ & 0.001 \\
\hline 5. & Khanna et al ${ }^{17}$ & 2016 & $8.106 \pm 0.7 \mathrm{fl}$ & $9.93 \pm 0.90 \mathrm{fl}$ & $<0.001$ \\
\hline 6. & Alhadas et al ${ }^{15}$ & 2016 & $7.90 \pm 0.790 \mathrm{fl}$ & $9.83 \pm 0.998 \mathrm{fl}$ & $<0.001$ \\
\hline 7. & Present study & 2019 & $10.39 \pm 0.75 \mathrm{fl}$ & $11.07 \pm 1.53 \mathrm{fl}$ & 0.0017 \\
\hline \multicolumn{6}{|c|}{$\begin{array}{l}\text { Table 4. Comparison of MPV in DMT2 (Controlled) \& } \\
\text { DMT2 (Uncontrolled) Groups in Various Studies }\end{array}$} \\
\hline
\end{tabular}

\section{DISCUSSION}

This study was carried out on 210 case out of which 150 cases are type 2 diabetes positive and 60 are non-diabetic control and Diabetic cases are further divided into controlled $(n=60)$ and uncontrolled group $(\mathrm{n}=90)$ by using HbA1c in controlled and uncontrolled group. We found significant $\mathrm{p}$ value on comparison of mean platelet volume of diabetic and nondiabetic cases. We also found significant $p$ value on comparison of mean platelet volume of controlled DMT2 cases and uncontrolled DMT2 cases.

Table No. 3 shows comparison of mean platelet volume of DMT2 and non-diabetic control group with significant $p$ value in various studies. It was well correlated with the studies done

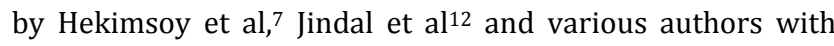
significant $\mathrm{p}$ value shown in table no 3 . Table No.4 shows comparison of mean platelet volume (MPV) of controlled DMT2 and uncontrolled DMT2 group with significant $p$ value in various studies. Same observations are found in studies done by Demirtunc et al, ${ }^{11} \mathrm{~S}$. Dindar et al, ${ }^{13}$ Aclan Ozder et al ${ }^{14}$ and other studies given in table no 4 . Study done by Kodiatte et $\mathrm{al}^{3}$ taken Uncontrolled DMT2 groups and controlled DMT2 groups according to the $\mathrm{HbA} 1 \mathrm{c}$ level as more than 6.5 percent and less than 6.5 percent respectively which is different from our study.

\section{CONCLUSIONS}

Mean platelet volume in diabetic mellitus type 2 patients was significantly higher than non-diabetic group. We also found that the mean platelet volume in uncontrolled diabetic group (HbA1c more than 7 percent) was significantly higher than controlled diabetic group (HbA1c less than 7 percent). Hence MPV along with HbA1c can be a useful diagnostic test as well as prognostic marker of vascular complications in DMT2 patients. MPV is an important parameter of routine haemogram, which is simple, inexpensive and less time consuming. So, it can also be useful in the early detection of vascular complication in DMT2 patients. We hope and recommend that this study will help in more effective management of vascular complications in DMT2 patients, as well as improve the present scenario.

\section{ACKNOWLEDGEMENT}

The authors thank Dr. Gautam Chandrakoshi, Dr. Swarna Das, Dr. Yogita Singh Tomar, Dr. Ankita Tripathi, Dr. Preeti Lahri, Dr. Lekha Ramchandani and the technical staff Mr. H. S. Dangi, Mr. Shyam, Mr. Jaiprakash and Mr. Arpit for extending all possible help during the research.

\section{REFERENCES}

[1] Mahsud MAJ, Khan A, Hussain J. Hematological changes in tobacco using type 2 diabetic patients. Gomal J Med Sci 2010;8(1):8-11.

[2] King H, Aubert RE, Herman WH. Global burden of diabetes, 1995-2025: prevalence, numerical estimates and projections. Diabetes Care 1998;21(9):1414-31.

[3] Kodiatte TA, Manikyam UK, Rao SB, et al. Mean platelet volume in type 2 diabetes mellitus. J Lab Physicians 2012:4(1):5-9.

[4] Alberti KG, Zimmet PZ. Definition, diagnosis and classification of diabetes mellitus and its complications. Part 1: diagnosis and classification of diabetes mellitus provisional report of a WHO consultation. Diabet Med 1998:15(7):539-53.

[5] Ostenson CG. The pathophysiology of type 2 diabetes mellitus: an overview. Acta Physiol Scand 2001;171(3):241-7. 
[6] Kaveeshwar SA, Cornwal J. The current state of diabetes mellitus in India. Australasian Med J 2014;7(1):45-8.

[7] Hekimsoy Z, Payzinb B, Ornek T, et al. Mean platelet volume in type 2 diabetes patients. J Diabetes Complecations 2004;18(3):173-6.

[8] Zuberi BF, Akhtar N, Afsar S. Comparison of mean platelet volume in patients with diabetes mellitus, impaired fasting glucose and non-diabetic subjects. Singapore Med J 2008;49(2):114-6.

[9] Calverley DC, Thienelt CD. Platelet structure and function in haemostasis and thrombosis. Wintrobe's Clinical Haematology. $12^{\text {th }}$ edn. Philadelphia: Lippincott Williams \& Wilkins 2009: p. 490-527.

[10] Skyler JS, Bergenstal R, Bonow RO, et al. Intensive glycemic control and the prevention of cardiovascular events: implications of the ACCORD, ADVANCE and VA diabetes trials: a position statement of the American Diabetes Association and a scientific statement of the American College of Cardiology Foundation and the American Heart Association. Circulation 2009;119(2):351-7.

[11] Demirtunc R, Dumanb D, Basara M, et al. The relationship between glycemic control and platelet activity in type 2 diabetes mellitus. Journal of Diabetes and its complications 2009;23(2):89-94.
[12] Jindal S, Gupta S, Gupta R, et al. Platelet indices in diabetes mellitus: indicators of diabetic microvascular complications. Journal Hematology 2011;16(2):86-9.

[13] Dindar S, Cinemre H, Sengul E, et al. Mean platelet volume is associated with glycaemic control and retinopathy in patients with Type 2 Diabetes Mellitus. West Indian Med J 2013;62(6):519-23.

[14] Ozder A, Eker HH. Investigation of mean platelet volume in patients with type 2 diabetes mellitus and in subjects with impaired fasting glucose: A cost-effective tool in primary health care? International Journal of Clinical and Experimental Medicine 2014;7(8):2292-7.

[15] Alhadas KR, Santos SN, Freitas MMS, et al. Are platelet indices useful in the evaluation of type 2 diabetic patients? J Bras Patol Med Lab 2016:52(2):96-102.

[16] Pujari MW, Desai PR. Correlation of glycosylated hemoglobin (HbA1c) and Mean Platelet Volume (MPV) in type ii diabetes mellitus patients and non-diabetic subjects. Journal of Advanced Medical and Dental Sciences Research 2017;5(11):86-9.

[17] Radha RKN, Selvam D. MPV in uncontrolled \& controlled diabetics-its role as an indicator of vascular complication. Journal of Clinical and Diagnostic Research 2016;10(8):EC22-EC6. 